\title{
OBSERVATION OF PHYSIOLOGICAL CHANGES AFTER DETOMIDINE ADMINISTRATION IN PATERI GOAT
}

\author{
Ahmed Tunio $^{1}$, Shamasuddin Bughio ${ }^{1}$, Jam Kashif Sahito ${ }^{1}$, \\ Muhammad Ghiasuddin Shah ${ }^{1}$, Mahdi Ebrahimi ${ }^{2}$, Shazia Parveen Tunio ${ }^{3}$ \\ ${ }^{1}$ Faculty of Animal Husbandry and Veterinary Sciences, \\ Sindh Agriculture University, Tandojam 70060, Pakistan \\ ${ }^{2}$ Faculty of Veterinary Medicine, Universiti Putra Malaysia \\ ${ }^{3}$ Social Science Research Institute, Tandojam, Pakistan \\ Received 25 June 2015; Received in revised form 19 October 2015; Accepted 3 December 2015
}

\begin{abstract}
The objective of this study was to determine the physiological effects of detomidine on Pateri goats. A total of six female Pateri goats were randomly treated with three different dose rates of Detomidine at $40 \mu \mathrm{g}, 50 \mu \mathrm{g}$ and $60 \mu \mathrm{g} / \mathrm{kg}$ body weights. The effects of Detomidine on respiratory and heart rate, rectal temperature and serum glucose level were investigated. Following detomidine intravenous administration in goats, it produced dose dependent effect on physiological parameters. Respiratory and heart rate decreased after intravenous administration in all goats. The heart rate decreased at 5 min with all dose rates and returned to the base line at $60 \mathrm{~min}$. This change in heart rate was dose dependent and there was no significant $(\mathrm{P}>0.05)$ change observed with $40 \mu \mathrm{g}$ and $50 \mu \mathrm{g} / \mathrm{kg}$ of Detomidine. However, there was significant difference $(\mathrm{P}<0.05)$ at 75 min between the $40 \mu \mathrm{g}$ and $60 \mu \mathrm{g} / \mathrm{kg}$ of Detomidine in all goats. However, significant $(\mathrm{P}<0.01)$ increase in serum glucose level occurred with all dose rates at 30 min compared with control groups. It is concluded that Detomidine has produced no adverse effect on physiological parameters.
\end{abstract}

Key words: Pateri goat, detomidine, respiratory rate, heart rate, glucose

\section{INTRODUCTION}

Goats undergo many surgical procedures, such as hernia, dystocia and traumatic injuries. Presently, Detomidine is used to provide good sedation and analgesia in horses $(1,2)$ at a dose rate of $10-20 \mu \mathrm{g} / \mathrm{kg}$ in horses (3). It is a highly potent drug, used for sedation in all animals, but has significant effect on physiological parameters. Results of several studies on the use of Detomidine have shown some impact on physiological parameters, with detomidine decreasing the heart rate, respiratory rate and then vital parameters returning to normal level slowly (4).

Corresponding author: Prof. Ahmed Tunio, $\mathrm{PhD}$

E-mail address: ahmedtuniodvm2009@gmail.com

Present address: Faculty of Animal Husbandry and

Veterinary Sciences, Sindh Agriculture University

Tandojam, 70060, Pakistan

Phone: 00923083889422

Copyright: (C 2015 Tunio A. This is an open-access article published under the terms of the Creative Commons Attribution License which permits unrestricted use, distribution, and reproduction in any medium, provided the original author and source are credited.

Competing Interests: The authors have declared that no competing interests exist.

Available Online First: 14 December 2015

Published on: 15 March 2016

http://dx.doi.org/10.1515/macvetrev-2015-0070
Meanwhile, Detomidine with $40 \mu \mathrm{g} / \mathrm{kg}$ decreases the respiratory rate, heart rate and rectal temperature, when used in sheep and goats respectively $(5,6)$. Beside this it increases the serum glucose level in goats $(7,8)$. Generally, goats kept for milk purpose on which various surgical procedures are performed and they need safe pre-anesthetics (9). Sedative and analgesics are used on goats for minor surgery, in order for animals to get relief from pain. Our practice suggests that application of Detomidine is a good choice for minor operations in goats. To our knowledge, there are limited reports available concerning the assessment of the physiological effects of Detomidine in goats. The purpose of this study was to assess whether Detomidine can be used in goats and have limited effects on physiological parameters. The hypothesis was that goats receiving Detomidine may have minimal effects on their physiological parameters in the case of minor and major clinical surgical procedures. The physiological effects of Detomidine are investigated to learn about the side effects and for future application. 


\section{MATERIAL AND METHODS}

This study was carried out in the Department of Surgery and Obstetrics, Faculty of Animal Husbandry and Veterinary Sciences, Sindh Agriculture University Tandojam. Six healthy Pateri female goats, aged between 6 to 8 months with body weight of $23.03 \pm 3.50 \mathrm{~kg}$ (mean $\pm \mathrm{SE}$ ) were used. All animals were purchased from the local market for this experiment. Goats received routine physical examination and they were found to be bright, alert and responsive during the study time. All animals were fed bursem grass and provided fresh water ad libitum. They were ear tagged from 1 to 6 for identification and were adapted for two weeks. The goats were randomly treated with three different dose rates of Detomidine (Dermosidan, $10 \mathrm{mg} / \mathrm{ml}$, Farmos Group ltd, Turku, Finland) as $40 \mu \mathrm{g} / \mathrm{kg}, 50 \mu \mathrm{g} / \mathrm{kg}$ and $60 \mu \mathrm{g} / \mathrm{kg}$ body weights. Each goat received three dose rates with 10 days interval between each treatment. After weighing the goats, hairs around left and right jugular vein sites were clipped using automatic hair clipper and prepared aseptically. The left jugular vein was used for intravenous administration of the drug using an $1 \mathrm{ml}$ disposable syringe. The right jugular vein was used for blood sample collection using a $3 \mathrm{ml}$ disposable syringe, transferred into plain tube and labeled as a control (before treatment) and treatment sample at intervals after drug administration. Physiological parameters were recorded before and after treatment, i.e., respiratory rate (RR) breaths/min were examined by counting thoracic movement in one minute, heart rate (HR) beats/min was taken from the left side of the thorax using a stethoscope and taken from all animals five minutes before the experiment as a control and then at 5, 15, $30,45,60,75,90,105$ and $120 \mathrm{~min}$. after treatment in all goats. The rectal temperature ${ }^{0} \mathrm{C}(\mathrm{RT})$ was obtained from each animal at five minutes before and then every $15 \mathrm{~min}$. up to $120 \mathrm{~min}$. post Detomidine administration using a clinical thermometer. For determination of the glucose level, venous blood samples $3 \mathrm{ml}$ were collected each time from the jugular vein as a control and then at 30,90 and 1440 min. after the administration of Detomidine. The blood samples were centrifuged at 4000 revolutions/min for 15 minutes and then the serum glucose was determined using a reflotron glucose test strip (Boehringer Mnnheim, Germany) on Reflotron Plus blood chemistry machine (Boehringer Mannheim Diagnostics, Germany).

\section{Statistical analysis}

The results obtained were analyzed using one way analysis of variance (ANOVA) with TukeyKramer multiple comparison test. All statistical tests were conducted at $95 \%$ confidence level.

\section{RESULTS}

\section{Respiratory rate (RR)}

The mean control values of respiratory rate (RR) breathe/min with three treatments were $18.66 \pm 0.98$, $19.33 \pm 1.11$ and $18.66 \pm 0.98$ in all goats respectively (Table 1). The Control values were not significantly different, respectively. RR decreased significantly at 30,15 and 5 minutes after administration of $40 \mu \mathrm{g} / \mathrm{kg}, 50 \mu \mathrm{g} / \mathrm{kg}$ and $60 \mu \mathrm{g} / \mathrm{kg}$ of Detomidine, respectively in all goats. The maximum decrease in $\mathrm{RR}$ occurred at $30 \mathrm{~min}$. in all dose rates. Then RR slowly returned to the base line by $60 \mathrm{~min} ., 90 \mathrm{~min}$. and $105 \mathrm{~min}$. after treatment of $40 \mu \mathrm{g} / \mathrm{kg}, 50 \mu \mathrm{g} / \mathrm{kg}$ and $60 \mu \mathrm{g} / \mathrm{kg}$ of Detomidine respectively, in all goats (Table 1).

Table 1. Mean $( \pm \mathrm{SE})$ respiratory rate with various dose rates of Detomidine in goats

\begin{tabular}{|c|c|c|c|}
\hline \multirow[t]{2}{*}{ Time (minutes) } & \multicolumn{3}{|c|}{ Detomidine dose rates } \\
\hline & $40 \mu \mathrm{g} / \mathrm{kg}$ & $50 \mu \mathrm{g} / \mathrm{kg}$ & $60 \mu \mathrm{g} / \mathrm{kg}$ \\
\hline 0 & $18.66 \pm 0.98$ & $19.33 \pm 1.11$ & $18.66 \pm 0.98$ \\
\hline 5 & $16.83 \pm 1.01$ & $15.66 \pm 0.95$ & $13.33 \pm 0.98 * *$ \\
\hline 15 & $14.83 \pm 0.65$ & $14.66 \pm 0.95 *$ & $12.00 \pm 0.51 * *$ \\
\hline 30 & $13.00 \pm 0.51 * *$ & $12.00 \pm 0.51 * *$ & $11.33 \pm 0.42 * *$ \\
\hline 45 & $13.50 \pm 0.50^{* *}$ & $13.66 \pm 0.80 * *$ & $11.66 \pm 0.61 * *$ \\
\hline 60 & $14.83 \pm 0.40$ & $14.00 \pm 0.73 * *$ & $12.00 \pm 0.73^{* *}$ \\
\hline 75 & $15.50 \pm 0.50$ & $14.66 \pm 0.66^{*}$ & $12.66 \pm 0.71 * *$ \\
\hline 90 & $17.00 \pm 0.44$ & $15.00 \pm 0.85$ & $14.16 \pm 0.90 *$ \\
\hline 105 & $18.00 \pm 1.03$ & $18.00 \pm 0.89$ & $15.33 \pm 1.08$ \\
\hline 120 & $18.66 \pm 0.98$ & $19.00 \pm 1.00$ & $18.66 \pm 0.98$ \\
\hline
\end{tabular}


Physiological changes after detomidine administration in Pateri goat

Table 2. Mean $( \pm \mathrm{SE})$ heart rate with various dose rates of Detomidine in goats

\begin{tabular}{|c|c|c|c|}
\hline \multirow[t]{2}{*}{ Time (minutes) } & \multicolumn{3}{|c|}{ Detomidine dose rates } \\
\hline & $40 \mu \mathrm{g} / \mathrm{kg}$ & $50 \mu \mathrm{g} / \mathrm{kg}$ & $60 \mu \mathrm{g} / \mathrm{kg}$ \\
\hline 0 & $76.33 \pm 1.58$ & $81.66 \pm 2.10$ & $76.16 \pm 2.59$ \\
\hline 5 & $50.16 \pm 4.24^{\text {aa }}$ & $48.33 \pm 2.10^{\text {aа }}$ & $47.33 \pm 1.60^{\text {aa }}$ \\
\hline 15 & $51.33 \pm 3.16^{\mathrm{aa}}$ & $50.83 \pm 2.34^{\text {aa }}$ & $47.33 \pm 1.14^{\text {aa }}$ \\
\hline 30 & $54.66 \pm 2.44^{\text {aa }}$ & $53.33 \pm 3.49^{\mathrm{aa}}$ & $43.50 \pm 0.88^{\text {aa }}$ \\
\hline 45 & $57.33 \pm 2.40^{\text {aa }}$ & $56.16 \pm 3.16^{\mathrm{aa}}$ & $47.50 \pm 1.02^{\mathrm{aa}}$ \\
\hline 60 & $62.50 \pm 3.33^{\mathrm{aa}, \mathrm{bb}}$ & $58.50 \pm 3.32^{\text {aа }}$ & $49.50 \pm 1.08^{\mathrm{aa}, \mathrm{bb}}$ \\
\hline 75 & $66.66 \pm 2.95^{\mathrm{bb}}$ & $64.00 \pm 3.81^{\text {aa, } \mathrm{c}}$ & $51.50 \pm 1.08^{\mathrm{aa}, \mathrm{bb}, \mathrm{c}}$ \\
\hline 90 & $69.00 \pm 3.64$ bb & $68.66 \pm 3.56^{\mathrm{a}, \mathrm{cc}}$ & $57.16 \pm 1.01^{\mathrm{aa}, \mathrm{bb}, \mathrm{cc}}$ \\
\hline 105 & $74.00 \pm 2.42^{\mathrm{b}}$ & $71.66 \pm 3.40$ & $62.50 \pm 1.25^{\mathrm{aa}, \mathrm{b}}$ \\
\hline 120 & $76.33 \pm 1.58$ & $78.33 \pm 2.27$ & $76.16 \pm 1.60$ \\
\hline
\end{tabular}

a $=$ Significant difference at $(\mathrm{P}<0.05)$ between the values and corresponding control

aa $=$ Significant difference at $(\mathrm{P}<0.01)$ between the values and corresponding control

$\mathrm{b}=$ Significant difference at $(\mathrm{P}<0.05)$ between the values of $40 \mu \mathrm{g} / \mathrm{kg}$ and $60 \mu \mathrm{g} / \mathrm{kg}$ at corresponding time

$\mathrm{bb}=$ Significant difference at $(\mathrm{P}<0.01)$ between the values of $40 \mu \mathrm{g} / \mathrm{kg}$ and $60 \mu \mathrm{g} / \mathrm{kg}$ at corresponding time

c $\quad=$ Significant difference at $(\mathrm{P}<0.05)$ between the values of $50 \mu \mathrm{g} / \mathrm{kg}$ and $60 \mu \mathrm{g} / \mathrm{kgat}$ corresponding time

cc $=$ Significant difference at $(\mathrm{P}<0.01)$ between the values of $50 \mu \mathrm{g} / \mathrm{kg}$ and $60 \mu \mathrm{g} / \mathrm{kg}$ at corresponding time

\section{Heart rate (HR)}

The mean control values of heart rate (HR) beats $/ \mathrm{min}$ in goats were $76.33 \pm 1.58,81.66 \pm 2.10$ and $76.16 \pm 2.59$ per min. respectively. Table 2 shows that mean control values were not different significantly from each other. However, PR decreased at $5 \mathrm{~min}$. with all doses and returned to base line at $60 \mathrm{~min}$., $90 \mathrm{~min}$. and $105 \mathrm{~min}$. after $40 \mu \mathrm{g} / \mathrm{kg}, 50 \mu \mathrm{g} / \mathrm{kg}$ and $60 \mu \mathrm{g} / \mathrm{kg}$ administration of Detomidine respectively. Detomidine showed that there was no significant difference in the PR rate in goats after all the treatment, but significant difference $(P<0.01)$ was observed from 60 to $90 \mathrm{~min}$. and at $105 \mathrm{~min}$. a significant difference $(\mathrm{P}<0.05)$ was observed between $40 \mu \mathrm{g} / \mathrm{kg}$ and $60 \mu \mathrm{g} / \mathrm{kg}$ of Detomidine respectively.

\section{Rectal temperature $\left({ }^{\circ} \mathrm{C}\right)$}

Mean control values of rectal temperature (RT) were $\quad 39.26 \pm 0.01^{\circ} \mathrm{C}, \quad 39.31 \pm 0.1^{\circ} \mathrm{C}, \quad 39.30 \pm 0.0^{\circ} \mathrm{C}$ in all goats respectively (Table 3 ). There were no significant difference observed between $40 \mu \mathrm{g} / \mathrm{kg}$, $50 \mu \mathrm{g} / \mathrm{kg}$ and $60 \mu \mathrm{g} / \mathrm{kg}$ of Detomidine in all goats respectively.

Serum glucose level

There was no significant difference in corresponding control values between all groups. However, there was significant difference $(\mathrm{P}<0.05)$ in the serum glucose level after Detomidine administration because this increase of glucose was dose dependent. Maximum increase in the serum glucose happened at 30 minutes when using all

Table 3. Mean $( \pm \mathrm{SE})$ rectal temperature $\left({ }^{\circ} \mathrm{C}\right)$ in goats after Detomidine administration at difference dose rates

\begin{tabular}{llll}
\hline Time (minutes) & \multicolumn{3}{c}{ Detomidine dose rates } \\
\cline { 2 - 4 } & $\mathbf{4 0} \boldsymbol{\mu g} / \mathbf{k g}$ & $\mathbf{5 0} \boldsymbol{\mu g} / \mathbf{k g}$ & $\mathbf{6 0} \boldsymbol{\mu g} / \mathbf{k g}$ \\
\hline 0 & $39.26 \pm 0.01$ & $39.31 \pm 0.1$ & $39.30 \pm 0.0$ \\
15 & $39.10 \pm 0.1$ & $39.05 \pm 0.1$ & $38.96 \pm 0.1$ \\
30 & $38.90 \pm 0.1$ & $38.80 \pm 0.1$ & $38.58 \pm 0.2$ \\
45 & $38.85 \pm 0.1$ & $38.48 \pm 0.3$ & $38.26 \pm 0.2$ \\
60 & $38.91 \pm 0.1$ & $38.30 \pm 0.3$ & $37.98 \pm 0.19$ \\
75 & $38.85 \pm 0.2$ & $38.18 \pm 0.3$ & $37.98 \pm 0.19$ \\
90 & $38.85 \pm 0.2$ & $38.26 \pm 0.2$ & $38.16 \pm 0.31$ \\
105 & $38.85 \pm 0.2$ & $38.65 \pm 0.3$ & $38.20 \pm 0.3$ \\
120 & $39.01 \pm 0.1$ & $39.15 \pm 0.1$ & $39.13 \pm 0.14$ \\
\hline
\end{tabular}


Table 4. Mean $( \pm \mathrm{SE})$ glucose level after administration of Detomidine in goats

\begin{tabular}{|c|c|c|c|}
\hline \multirow[t]{2}{*}{ Time (minutes) } & \multicolumn{3}{|c|}{ Detomidine dose rates } \\
\hline & $40 \mu \mathrm{g} / \mathrm{kg}$ & $50 \mu \mathrm{g} / \mathrm{kg}$ & $60 \mu \mathrm{g} / \mathrm{kg}$ \\
\hline 0 & $66.91 \pm 2.32$ & $64.80 \pm 2.39$ & $64.01 \pm 2.70$ \\
\hline 30 & $125.67 \pm 3.75$ aa, dd & $139.33 \pm 4.39$ dd & $154.83 \pm 4.56$ aa, dd \\
\hline 90 & $83.56 \pm 3.01^{\mathrm{b}, \mathrm{d}, \text { fi }}$ & $101.52 \pm 2.49$ চb, fí, dd & $127.17 \pm 5.80^{d d, d d, ~ m m}$ \\
\hline 1440 & $65.50 \pm 2.23$ & $63.96 \pm 2.69$ & $62.13 \pm 2.42$ \\
\hline
\end{tabular}

aa $=$ Significant difference at $(\mathrm{P}<0.01)$ between the values of $40 \mu \mathrm{g} / \mathrm{kg}$ and $60 \mu \mathrm{g} / \mathrm{kg}$ at corresponding time

万 $=$ Significant difference at $(\mathrm{P}<0.05)$ between the values of $40 \mu \mathrm{g} / \mathrm{kg}$ and $50 \mu \mathrm{g} / \mathrm{kg}$ at corresponding time

$\downarrow=$ Significant difference at $(\mathrm{P}<0.05)$ corresponding control

$\delta d=$ Significant difference at $(\mathrm{P}<0.01)$ corresponding control

$\mathrm{mm}=$ Significant difference at $(\mathrm{P}<0.01)$ between the values of $40 \mu \mathrm{g} / \mathrm{kg}$ and $60 \mu \mathrm{g} / \mathrm{kg}$ at corresponding time

$\hat{\mathrm{h}} \mathrm{h}=$ Significant difference at $(\mathrm{P}<0.01)$ between the values of $50 \mu \mathrm{g} / \mathrm{kg}$ and $60 \mu \mathrm{g} / \mathrm{kg}$ at corresponding

three doses and then the serum glucose level started to return gradually from 90 minutes up-to 24 hours. The mean values for the serum glucose level were significantly decreased at 30 minutes $(\mathrm{P}<0.05)$ with $40 \mu \mathrm{g} / \mathrm{kg}$ as compared to values with $50 \mu \mathrm{g} / \mathrm{kg}$ of Detomidine (Table 4). Similarly mean values were significantly lower at 30 minutes $(\mathrm{P}<0.01)$ and 90 minutes with $40 \mu \mathrm{g} / \mathrm{kg}$ as compared to values with $50 \mu \mathrm{g} / \mathrm{kg}$ of Detomidine. Similarly mean values were significantly lower at $30 \mathrm{~min}$. $(\mathrm{P}<0.01)$ and $90 \mathrm{~min}$. with $40 \mu \mathrm{g} / \mathrm{kg}$ as compared to corresponding values with $60 \mu \mathrm{g} / \mathrm{kg}$ of Detomidine. Mean values were significantly lower at $90 \mathrm{~min}$. $(\mathrm{P}<0.01)$ with $50 \mu \mathrm{g} / \mathrm{kg}$ as compared to corresponding values with $60 \mu \mathrm{g} / \mathrm{kg}$ of Detomidine.

\section{DISCUSSION}

Data on the physiological effects of detomidine in goat is limited. The respiratory rate (RR) decreased significantly in all goats in this study, which is similar to the findings observed in goats (6), in horses $(4,10,11)$ and in calves (12). However, on the other hand in sheep it was observed that Detomidine had accelerated the respiratory rate in the first $15 \mathrm{~min}$. with Detomidine $(5,7)$. The heart rate decreased after Detomidine administration of $40 \mu \mathrm{g} / \mathrm{kg}, 50 \mu \mathrm{g} / \mathrm{kg}$ and $60 \mu \mathrm{g} / \mathrm{kg}$ in all goats. Similarly, decrease in the heart rate has been reported in horses $(4,10,13)$ as well in sheep's (5) and in buffalo's (14). While rectal temperature in this study slightly decreased after administration of Detomidine, this decrease was not significant compared to the control values. Previous study by Singh et al. (6) reported that in goats rectal temperature decreased with $40 \mu \mathrm{g} / \mathrm{kg}$ of Detomidine. In other animals Detomidine also had an effect on body temperature, with decreases in calves (12) and in sheep's (7).
In this study increase in serum glucose occurred in all goats and this increase of the serum glucose is also in agreement with results published by Ambrósio, A. M. et al. (15), where serum glucose increased because Detomidine has an anti-insulin effect and stimulates the alpha- 2 receptors in pancreas resulting in increased blood glucose level. This effect on the blood glucose was due to Detomidine in this study. Similarly it was reported that glucose increased in sheep with Detomidine at $30 \mu \mathrm{g} / \mathrm{kg}, 60 \mu \mathrm{g} / \mathrm{kg}$ and $90 \mu \mathrm{g} / \mathrm{kg}$ dose rates (7). Increase in the serum glucose level was also reported by other recherches in goats $(6,8)$.

\section{CONCLUSION}

The study revealed that Detomidine has no adverse effects on physiological parameters. In addition, the effects on physiological parameters remained dose dependent, proving Detomidine is useful for goats. Further physiological study is needed to confirm these findings.

\section{REFERENCES}

1. Grimsrud, K. N., Mama, K. R., Thomasy, S. M., Stanley S. D. (2009). Pharmacokinetics of detomidine and its metabolites following intravenous and intramuscular administration in horses. Equine Vet J. 41 (4): 361-365.

http://dx.doi.org/10.2746/042516409X370900 PMid:19562897

2. Mama, K. R., Grimsrud, K., Snell, T., Stanley, S. (2009). Plasma concentrations, behavioural and physiological effects following intravenous and intramuscular detomidine in horses. Equine Vet J. 41 (8): 772-777.

3. Hall, L.W., Clarke, K.W. (1991). Veterinary anesthesia. $9^{\text {th }}$ ed, Bailler Tindall. 191-193.

PMid:1889172 
Physiological changes after detomidine administration in Pateri goat

4. Jochle, W. (1990). Dose selection for Detomidine as a sedative and analgesic in horses with colic from controlled and open clinical studies. J. Equine. Vet. Scs. 10 (1): 6-11.

http://dx.doi.org/10.1016/S0737-0806(06)80075-4

5. Komar, E. (1989). Detomidine as a sedative in sheep. Folia Veterinaria 33, 9-17.

6. Singh, A. P., Peshin, P. K., Singh, J., Sharifi, D., Patil, D. B. (1990). Evaluation of detomidine as a sedative in goats. Acta Veterinaria Hungarica 39 (3-4): 109-114.

7. Singh, J., Singh, A. P., Peshin, P. K., Sharifi, D., Patil, D. B. (1994). Evaluation of Detomidine as a sedative in sheep. Indian J Ani Sci. 63 (3): 237-238.

8. Dilip, K.D., Sharma, A. K., Gupta O. P. (1997). Studies on hematological and biochemical changes induced during alpha adrenoreceptor against sedation in goats. Indian Vet.J. 74 (6): 496-498.

9. Zeedan, K. I., El-Malky, O. M., El-Ella, A. A. (2014). Nutritional, physiological and microbiological studies on using biogen-zinc on productive and reproductive performance of ruminants. 2-productive performance, digestion and some blood components of Damascus goats. Egyptian J Sheep and Goat Sci. 9 (3): 49-66.

10. Aguiar, A. J., Hussni, C. A., Luna, S. P., Castro, G. B., Massone, F., Alves, A. L. (1993). Propofol compared with propofol $\mathrm{V}$ guaiphenesin after detornidine premedication for equine surgery. Vet Anaes Analg. 20 (1): 26-28.

http://dx.doi.org/10.1111/j.1467-2995.1993.tb00105.x
11. Skarda, R. T., Muir, W. W. (1996). Comparison of antinociceptive, cardiovascular, and respiratory effects, head ptosis, and position of pelvic limbs in mares after caudal epidural administration of xylazine and detomidine hydrochloride solution. American J Vet Res. 57 (9): 1338-1345.

PMid:8874730

12. Garcia, O.H., Errecalde, C., Prieto, G. (1991). Clinical evaluation of intravenous detomidine hydrochloride in calves. Veterinary argent. 8 (74): 248-251.

13. Short, C.E. (1992). The response to the use of Detomidine (Domosedan) in the horse. WienerTieraztliche-Monatsschrift 79 (1): 2-12.

14. Silva, D.D.N., Dangolla, A., Silva, L.N.A. (1991). Preliminary studies on sedative analgesic effects of Detomidine (dermosidan) in buffalo calves. Srilanka Vet. J. 38, 26.

15. Ambrósio, A. M., Casaes, A. G., Ida, K. K., Souto, M. T., Silva, L. da. Furtado, P. V., Fantoni, D.T. (2012). Diferenças no aumento da glicemia entre equinos recebendoxilazina e detomidina para procedimento sclínico scirúrgicos e não-cirúrgicos. Braz J Vet Res Ani Sci. 49 (6): 493-499.

http://dx.doi.org/10.11606/issn.1678-4456. v49i6p493-499 